«Системні технології» 6 (131) 2020 «System technologies»

DOI 10.34185/1562-9945-6-131-2020-11

UDC $621.355: 656.2$

V. Kuznetsov, Yu. Kachan

\title{
ABOUT THE EXPEDIENCY OF USING ELECTROCHEMICAL STORAGES IN POWER SUPPLY SYSTEMS FOR NON-TRACTION CONSUMERS OF RAILWAYS FROM RENEWABLE ENERGY SOURCES
}

Annotation. This paper focuses on the problem of analyzing expediency of using electrochemical storages in power supply systems for non-traction consumers of railways from renewable energy sources (RES). It is quite obvious that RES implementation in any national industry as a proper distributed energy source is too problematic if there is no possibility to accumulate it in good supply. The aim of this paper is to select the most appropriate electrochemical storage device for power systems for non-traction consumers of railways from RES. The methodology of research is based on modern methods of computational mathematics, statistics and information analysis using modern computer technology. Consequently, the analysis helps conclude that $\mathrm{LiFePO}_{4}$ batteries are the most preferable for power lines. That especially concerns railway mains with RES use since the batteries have the best power characteristics.

Keywords: electrochemical buttery, lithium batteries, lead-acid storage cells, renewable energy sources, quality of electric energy, alkaline energy batteries, power supply networks of railway transport, traction and non-traction consumers.

Formulation of the problem. It is quite obvious that RES implementation in any national industry as a proper distributed energy source is too problematic if there is no possibility to accumulate it in good supply. Otherwise, it will result in numerous extra problems connected with two-directional power exchange; unacceptable power fluctuations; deterioration of electromagnetic compatibility within the mains etc.

Large-scale RES use for railway transport is also impossible until the problem is solved. It is absolutely necessary to make clear recommendations concerning the most acceptable means of electric energy accumulation taking into consideration each specific feature of railway mains.

As it is known, there are several techniques to accumulate electric power. First of all, they are accumulator batteries, two-layer electrostatic condensers, and gasand hydro-accumulating systems. It also concerns hydrogen production and accu-

(C) Kuznetsov V., Kachan Yu., 2020 


\section{«Системні технології» 6 (131) 2020 «System technologies»}

mulation being too expensive currently. Thus, it is necessary to identify features of the tendencies as well as their potential to be used by railway transport.

Analysis of previous research and publications. It is known [1] that energy resources largely determine the economic situation both in Ukraine and in the modern world as a whole. For Ukraine, solving the problems of energy saving and energy efficiency has become one of the top priorities. Since the railway is today the main consumer of electrical energy, the reduction of energy intensity and the energy component of the prime cost of freight and passenger transportation is one of the determining factors for effective development. The power supply system of railway transport is an important link in the technological cycle of production, transmission and consumption of electricity [1,2]. The problem of reducing the consumption of electric energy in the power supply systems of non-traction consumers can be partially solved through the introduction of RES, however, the problem of accumulation of generated electricity by the above sources remains unresolved [2].

Currently, there is a wide range of energy storage systems, however, the most widespread are electrochemical storage systems. The latter have found application in traction and non-traction power supply systems for urban and suburban rail transport in the USA, EU countries, Japan and Russia, while the energy consumption of storage systems used in transport does not exceed $1000 \mathrm{~kW} \cdot \mathrm{h}$ and is determined by the characteristics of the load and the tasks solved in this case [3].

Moreover [3-5], electric energy storage systems in the power supply systems of railway transport solve the following tasks: ensuring the required voltage level in case of emergency or technological shutdown; stabilization of the voltage level at the point of connection; increasing the efficiency of the use of regenerative braking; increasing the energy efficiency of transportation.

The aim of this paper is to select the most appropriate electrochemical storage device for power systems for non-traction consumers of railways from RES.

Possibilities of lead-acid storage cells. Start from the first abovementioned means to accumulate energy, i.e. electrochemical storage cell. In 1859, G. Plante invented an effect of energy concentration within a lead-acid medium owing to which the storage cell showed up. Using it, K. Faure developed the first efficient electrochemical device in 1881. Despite the fact that later other accumulator types have been produced, a lead-acid one is still popular.

The storage cell is based upon a galvanic pair which EMF is almost 2 Volts. Now, a lead-acid storage cell (LASC) is composed in such a way to provide 6 or 12 Volts. Then, the storage cells are integrated into blocks to apply a value of the latter 124 


\section{«Системні технологіï» 6 (131) 2020 «System technologies»}

(for instance, 24, 48, 96, 120 and more volts). According to a double sulfation theory, the basic current-forming process within a LASC is as follows [6]:

$$
\mathrm{Pb}+\mathrm{PbO}_{2}+2 \mathrm{H}_{2} \mathrm{SO}_{4} \stackrel{\text { CHARGE-DISCHARGE }}{\longrightarrow} 2 \mathrm{PbSO}_{4}+2 \mathrm{H}_{2} \mathrm{O} .
$$

In terms of equation (1), when SC of the electrochemical system takes place, acid $\mathrm{H}_{2} \mathrm{SO}_{4}$ concentration within the electrolyte solution decreases. In turn, concentration of dissolver $\mathrm{H}_{2} \mathrm{O}$ and lead sulfate $\mathrm{PbSO}_{4}$ increases. That reduces electrical conductivity of the electrolyte as well as voltage within the device terminals. Thus, the latter varies significantly during a process of charging/discharging.

Voltage fluctuations may also result from changes in crystalline modification of the SC cathode factoring into instability of electrode potential $\left(E^{0}\right)$ of the latter. It is known that lead dioxide, the electrode consists of, can exist in rhombic modification $\left(\alpha-\mathrm{PbO}_{2}\right)$ and in tetragonal one $\left(\beta-\mathrm{PbO}_{2}\right)$. The former is formed in terms of relative acidity within the cathode pores.

When almost discharged LASC is being charged and $\mathrm{H}_{2} \mathrm{SO}_{4}$ concentration within the electrolyte is small (i.e. $\mathrm{PbSO}_{4}$ and $\mathrm{H}_{2} \mathrm{O}$ amount increases), probability of rhombic modification increases; in terms of normal temperature and pressure, electrode potential drops down to $E^{0}=1.6871$. At the same time, probability of tetragonal structure $\left(\beta-\mathrm{PbO}_{2}\right)$ is maximal when such a storage cell is almost charged. In this context, a value of electrode potential of the cathode grows up to $E^{0}=1.7971 \mathrm{~V}$.

In addition to electrolyte composition, current density in the process of the SC charging/discharging also influences heavily crystalline modification and the mentioned potential of a positive electrode being quite smaller during final intervals of the processes.

Capacity $C$ of such a storage cell is not still under the conditions too. It depends heavily upon discharge current $i_{p}$ which can be explained while using Peukert equation [7]:

$$
C=\frac{A}{i_{p}^{n}},
$$

where $A$ and $n$ are empiric coefficients.

However the dependence is widely used now, it is typical for the specified discharge current since in terms of heavy current or small current it is in significant errors as for the SC capacity determination. 


\section{«Системні технологіï» 6 (131) 2020 «System technologies»}

The capacity depends heavily upon the environmental temperature as well. In terms of temperature variation, decrease or increase in its amount can also be described with the help of the known dependence

$$
C_{t_{2}}=\frac{C_{t_{1}}}{1+\alpha\left(t_{2}-t_{1}\right)},
$$

where $t_{1}$ and $t_{2}$ are the temperature values in the mentioned sequence as for time; and $\alpha$ is temperature coefficient of the capacity.

However, self-discharge rate is more important characteristic of LASC to apply it. In the context of dioxide-lead electrode it is described with the help of the equation

$$
\mathrm{PbO}_{2}+\mathrm{HSO}_{4}^{-}+\mathrm{H}^{+}=\mathrm{PbSO}_{4}+\mathrm{H}_{2} \mathrm{O}+\frac{1}{2} \mathrm{O}_{2} .
$$

The rate is identified by means of oxygen release on it. In this context, if the electrode is of tetragonal modification than SC discharge lasts twice slower to compare with the rhombic one. Consideration of the fact that its prolonged operation life (in terms of charge/discharge cycles) results in gradual $\alpha$ modification to $\beta$ helps conclude that self-discharge rate of the electrode increases.

As for the lead electrode (i.e. anode), its electrochemical process, determining mainly SC self-discharge rate, is described using the equation

$$
\mathrm{Pb}+\mathrm{HSO}_{4}^{-}=\mathrm{PbSO}_{4}+\mathrm{H}^{+}+2 e^{-} .
$$

Along with the cell charging, increase in sulfate ion concentration takes place. In turn, the process results in the decreased potential of the electrode.

According to [8], in the context available cases of RES use, lead-acid cells are mainly charged at constant voltage with the application of traditional charging devices. Current is also maintained constant at the initial stage. Then only voltage value is controlled within each element of the SC. In terms of $20 \div 25^{\circ} \mathrm{C}$ temperature it should be almost $2.45 \mathrm{~V}$ right to the process end.

So called floating charge is the most expedient measure for the use when the storage capacity is connected in parallel with load and charge/discharge is of chaotic nature. It is almost impossible to implement the procedure for LASC. Moreover, a procedure of regenerative charging applied for urgent cases when SC is close to complete discharge is absolutely inacceptable. Nevertheless, SC cannot remain discharged since it will result in sulfation of plates and considerable decrease of its capacitance or even failure. 
«Системні технології» 6 (131) 2020 «System technologies»

Thus, availability of significant self-discharge of LASCs, stipulating their low efficiency and productivity as well as operation complexity in the case of chargedischarge processes, makes lead-acid accumulating devices undesirable within the electric power supply grids with wind and solar energy sources.

Alkaline energy batteries and their differences. Accumulating devices, differing from lead-acid electrochemical systems, came to existence early in the $20^{\text {th }}$ century owing to the invention by Thomas Edison in 1901. He proposed nickel-iron secondary energy source consisting of oxide-nickel cathode, iron anode, and alkaline electrolyte. Current-forming process of such an accumulator is described by means of the expression

$$
\mathrm{Fe}+2 \mathrm{NiOOH}+2 \mathrm{H}_{2} \mathrm{O} \stackrel{\text { CHARGE-DISCHARGE }}{\longrightarrow} \mathrm{Fe}(\mathrm{OH})_{2}+2 \mathrm{Ni}(\mathrm{OH})_{2} .
$$

To compare with LASC, only water is lost in the process of the nickel-iron (NI) accumulator discharge. Electrolyte ( $\mathrm{NaOH}$ or $\mathrm{KOH}$ alkalis) is responsible for a charge transfer through first-class conductor and second-class conductor phase separation. As for the processes on a cathode of the electrochemical systems, they are more complex. First, the fact is stipulated by their solid phase nature as well as the availability of $\beta$ - and $\gamma$-modifications of $\mathrm{NiOOH}$.

As a result of the mentioned features, a process of NiFe battery charge form oxides with more than 3+ oxidation nickel rate. Generally, the processes, taking place on a cathode, are described as follows:

$$
\mathrm{NiOOH}+\mathrm{H}_{2} \mathrm{O}+e^{-} \stackrel{\text { CHARGE-DISCHARGE }}{\longrightarrow} \mathrm{Ni}(\mathrm{OH})_{2}+\mathrm{OH}^{-} .
$$

However, the case does not demonstrate electrode deformation owing to the identity of crystalline lattice of $\beta-\mathrm{NiOOH}$ and $\beta-\mathrm{Ni}(\mathrm{OH})_{2}$ modification while the battery charging/discharging. Nevertheless, because of considerably higher conductivity of $\mathrm{NiOOH}$ hydroxide to compare with $\mathrm{Ni}(\mathrm{OH})_{2}$, a process of $\mathrm{NiOOH}$ iterating should be introduced gradually not more than by $80 \%$. The matter is that if concentration of alkaline or charging current is high then $\gamma-\mathrm{NiOOH}$ modification with less density may rise. That results in electrode swelling [9].

After the accumulator is discharged by half, secondary process starts. Then, high nickel oxides, formed while charging, start resolving with oxygen release. That becomes one of the reasons of rapid self-discharge of just charged oxide-nickel cathodes.

Anode process is not less complex [10]. Hematite $\left(\mathrm{Fe}_{2} \mathrm{O}_{3}\right)$, magnetite $\left(\mathrm{Fe}_{3} \mathrm{O}_{4}\right)$ or thermally reduced iron are applied to manufacture the electrode. Dibasic or tribasic iron hydroxide form (i.e. $\mathrm{Fe}(\mathrm{OH})_{2}$ or $\mathrm{Fe}(\mathrm{OH})_{3}$ ) form while charging. That 


\section{«Системні технології» 6 (131) 2020 «System technologies»}

depends upon a potential on the anode. If the potential varies within $-0.4 \div-1.1$ then the former originates; if $+0.4 \mathrm{~V}$ is exceeded then iron oxidation up to +3 degree takes place and tribasic oxide evolves. In terms of higher values of the potential, even $\mathrm{FeO}_{4}^{2-}$ anions may form which results in the electrode failure.

Like with the previous accumulator type, anode also has a tendency to decomposition. The process takes place in alkaline solution with hydrogen release. In addition to the situation, anode decomposition process with oxygen uptake is also possible. The abovementioned stipulates considerable self-discharge of the accumulator. On the whole, the self-discharge process of nickel-iron accumulator are described as follows:

$$
\begin{gathered}
\mathrm{Fe}+2 \mathrm{H}^{+} \rightarrow \mathrm{Fe}^{+}+\mathrm{H}_{2}, \\
\mathrm{Fe}+\frac{1}{2} \mathrm{O}_{2}+\mathrm{H}_{2} \mathrm{O} \stackrel{\text { CHARGE-DISCHARGE }}{\longrightarrow} \mathrm{Fe}(\mathrm{OH})_{2} .
\end{gathered}
$$

Despite the fact that self-discharge of electrode, made of pure iron, may be $40 \%$ per months and up to $80 \%$ in terms of ingot iron, the accumulators under consideration, have following considerable advantages: each component, formed while SC charging/discharging, cannot be dissolved in electrolyte or react with other chemicals; NiFe batteries can reside in the discharged state for a long period of time which is absolutely inacceptable for LASCs; alkaline accumulators resist considerable overloads; hence, they may have heavy charge current and discharge current; and owing to high internal resistance, NiFe batteries can remain serviceable even if undurable short circuits take place or severe degree of discharge.

As for the NiFe battery charging, then, according to [11], it is done with the help of small direct current during 6-7 hours until a potential within each element of the battery achieves $1.75 \ldots . .1 .9 \mathrm{~V}$. It is the moment when active electrolyte "boiling" starts within each element. Charging of the accumulators should involve constant control of the electrode temperature as well to prevent it from exceeding $+40^{\circ} \mathrm{C}$. If that happens, it is necessary to reduce charging current. Accelerated charging of alkaline accumulators is followed by intensive gas release. Hence, their use in electric power supply systems with RES is problematic involving further studies.

Generally, railway transport applies NiFe batteries as the batteries for diesel locomotives. Such studies are even known [12] proposing their charging with the help of two-stage current with the accumulated energy control. Transition to another value of charge current is recommended depending upon the voltage value and CS temperature. 


\section{«Системні технології» 6 (131) 2020 «System technologies»}

Invention by Will helped increase opportunities of alkaline SCs. He patented nickel metal hydride battery (NiMH) in 1975 . When $\mathrm{La}-\mathrm{Ni}-\mathrm{Co}$ alloy became available it was implemented for the first time. The alloy made it possible to adsorb hydrogen reversely during 100 charge/discharge cycles.

Current forming electrochemical reaction of nickel metal hydride batteries takes place according to the equation:

$$
\mathrm{Ni}(\mathrm{OH})_{2}+\mathrm{M} \stackrel{\text { CHARGE-DISCHARGE }}{\longleftrightarrow} \mathrm{MH}+\mathrm{NiOOH} .
$$

During the reaction when SC is charged, protons are transferred from oxidenickel cathode to anode. They move in the opposite direction when discharge takes place. Anode is manufactured using alloy of several metals. Like in the previous case, electrolyte concentration, being alkaline solution, remains constant.

Generally, electrochemical process, taking place on the cathode, is described as follows

$$
\mathrm{Ni}(\mathrm{OH})_{2}+\mathrm{OH}^{-} \stackrel{\text { CHARGE-DISCHARGE }}{\longrightarrow} \mathrm{NiOOH}+\mathrm{H}_{2} \mathrm{O}+e^{-} .
$$

When the SC achieves its nominal capacitance while charging, oxygen release starts on a cathode. Then the oxygen diffuses through a porous retainer to anode recovering on it. The closed oxygen cycle helps stabilize pressure inside the battery.

Hydrogen starts releasing on a cathode, which left its all active components, during a SC charge. The reaction is as follows

$$
2 \mathrm{H}_{2} \mathrm{O}+2 e^{-} \stackrel{\text { OVERDISCHARGE }}{\longrightarrow} \mathrm{H}_{2}+2 \mathrm{OH}^{-} \text {. }
$$

The hydrogen diffuses through porous electrode up to anode surface oxidizing on it.

Once again, the reaction of hydrogen formation on a cathode and its oxidization on anode while the battery recharging implements the closed type as for the hydrogen as well. Moreover, it helps stabilize pressure in the case too. Hence, the NiMH batteries may be manufactured in an airtight form.

As for the material, applying to produce anode and determining NiMH battery characteristics, it is an alloy able to absorb oxygen amount being quite larger to compare with proper one (thousandfold). Hydrogen absorption and desorption in the process of SC charging/discharging result in almost 15\% decrease/increase in crystalline lattice of the selected alloy. Usually, the latter consists of one metal, absorbing hydrogen exothermally, and another one, forming hydrides with heat absorption.

To compare with prior accumulating facilities, slow charge of NiMH battery (called as a trickle charge) decreases capability resource of the latter. The only ad- 


\section{«Системні технології» 6 (131) 2020 «System technologies»}

vantage of the charge is its simpler implementation requiring no recording of the process termination since charge current within a SC continues flowing even if its nominal capacitance is achieved. Moreover, the procedure prevents the battery from heating.

Rapid NiMH battery charge, performed at $(0 \div+40)^{0} \mathrm{C}$ temperature and (0.8...1.8) V voltage on terminals, is of very high efficiency as for the storage cells (almost 90\%). However, at the end of the process the latter experiences moderate decrease since the whole energy, getting to the SC, starts transforming into heat.

Despite the fact that NiMH batteries are used currently by electric supply systems, they are also charged by stationary sources. Actually, their applicability for systems with RES is understudied. Thus, they need further research inclusive of their use as buffer butteries in railway mains.

Characteristics and advantages of lithium batteries. Finally, consider comparatively new and the advanced energy storage units which primary element was proposed in the 1970s. Despite the fact that early lithium battery started up in 1991, today the devices are the most popular. Principally, it can be explained by their specific energy characteristics; long suitability life; and minor self-discharge to compare with lead-acid, nickel-iron or even NiMH batteries.

The latter is stipulated by specificity of lithium electrode covered with a passive film in any electrolyte. It has conductivity of solid electrolyte in terms of lithium ions which prevents active anode material from corrosion as well as self-discharge intensification.

Rise in lithium SCs is a very rapid process. According to [13], only in 2000-2015 the total annual capacitance of lithium batteries, entered a market, increased from 10000 up to $60000 \mathrm{MW} \cdot \mathrm{h}$ to compare with those ones, considered before, which remained at their previous level being $10000 \mathrm{MW} \cdot \mathrm{h}$. Mainly, the growth falls at various needs of traction electric transport [14-15].

Currently, the three types of lithium SCs are known: with metal lithium electrode and liquid electrolyte; rechargeable lithium-ion cells; and lithium-pol ones.

In terms of the former, current-formation electrochemical reaction on anode is performed according to the equation:

$$
\mathrm{Li} \stackrel{\text { CHARGE-DISCHARGE }}{\longrightarrow} \mathrm{Li}^{+}+e^{-} .
$$

As for the rechargeable lithium-ion cells, the reaction follows the expression:

$$
x \mathrm{Li}^{+}+x e^{-}+6 C \stackrel{\text { CHARGE-DISCHARGE }}{\longleftrightarrow} \mathrm{Li}_{x} \mathrm{C}_{6}+e^{-} .
$$


«Системні технології» 6 (131) 2020 «System technologies»

Battery cathodes of the two mentioned types are manufactured using lithium oxides of cobalt or nickel as well as lithium-manganese spinels. In the process of the electrode charge/discharge, lithium intercalation and deintercalation take place in terms of the equations

$$
\begin{gathered}
\mathrm{LiCOO}_{2} \stackrel{\text { 3CHARGE-DISCHARGE }}{\longrightarrow} \mathrm{Li}^{+}+e^{-}+\mathrm{CoO}_{2} ; \\
\mathrm{LiNiO}_{2} \stackrel{\text { CHARGE-DISCHARGE }}{\longrightarrow} \mathrm{Li}^{+}+e^{-}+\mathrm{NiO}_{2} ; \\
\mathrm{LiMn}_{2} \mathrm{O}_{4} \stackrel{\text { CHARGE-DISCHARGE }}{\longrightarrow} 2 \mathrm{Li}^{+}+2 e^{-}+2 \mathrm{MnO}_{2} .
\end{gathered}
$$

Concerning the methods to charge lithium storage cells, the majority of their manufacturers recommend performing the process during 2-3 hours according to a two-stage procedure. First, it is required to support minor direct current until the specified voltage value is achieved; then, the value should be supported as a constant one. In this case, stage one is $70-80 \%$ of the storage cell state of charge. However, the idea of rapid charge has already been confirmed especially in terms of lithium-ion batteries [48]. The paper mentions the fact that a SC, which walls are covered with metal foil, was charged up to $80 \%$ of its capacitance for 14 minutes. It withstood more than 500 cycles of such charging conditions.

Thus, in this regard lithium batteries, which basic specifications are listed in Table 1, have significant potential as for their use by electric power supply systems with the renewable energy sources as well.

\begin{tabular}{|c|c|c|c|c|c|c|}
\hline \multirow[b]{2}{*}{ 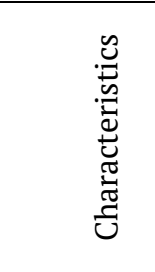 } & \multicolumn{6}{|c|}{ Name and abbreviation of storage batteries } \\
\hline & 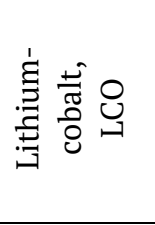 & 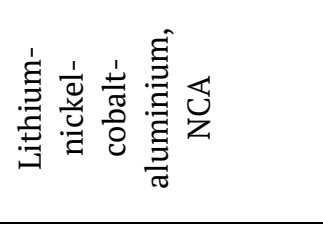 & 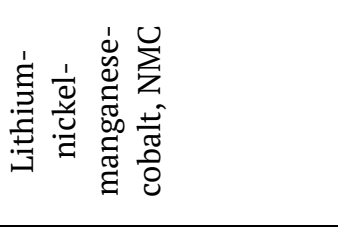 & 竞 & 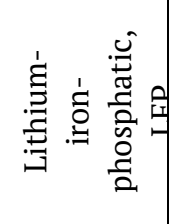 & 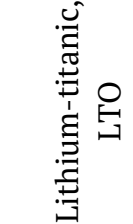 \\
\hline 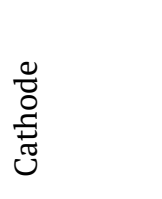 & $\mathrm{LiCoO}_{2}$ & $\operatorname{Li}\left(\mathrm{Ni}_{0,85} \mathrm{Co}_{0,1} A l_{0,05}\right) \mathrm{O}_{2}$ & $\operatorname{Li}\left(\mathrm{Ni}_{0,33} \mathrm{Mn}_{0,33} \mathrm{Co}_{0,33}\right) \mathrm{O}_{2}$ & $\mathrm{LiMn}_{2} \mathrm{O}_{4}$ & $\mathrm{LiFePO}_{4}$ & 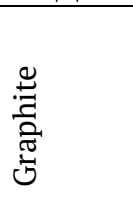 \\
\hline $\begin{array}{l}\frac{\pi}{0} \\
\frac{\pi}{4}\end{array}$ & 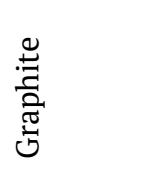 & 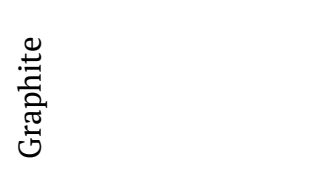 & 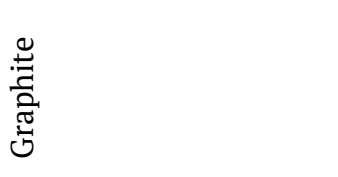 & 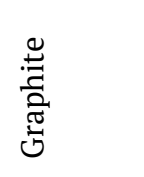 & 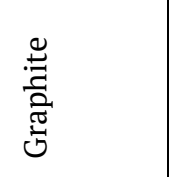 & $\mathrm{Li}_{4} \mathrm{Ti}_{5} \mathrm{O}_{12}$ \\
\hline $\begin{array}{l}\text { Unit volt- } \\
\text { age, V: } \\
\text {-nominal; } \\
\text { - working } \\
\text { range. }\end{array}$ & $3.0 \ldots .4 .2$ & $3.0 \ldots .4 .2$ & 3.6...3.7 & $\begin{array}{c}3.7 \\
3.0 \ldots . .4 .2\end{array}$ & $\begin{array}{l}3.2 \ldots 3.3 \\
2.5 \ldots 3.6\end{array}$ & $\begin{array}{c}2.4 \\
1.8 \ldots 2.8\end{array}$ \\
\hline
\end{tabular}

Table I

Specifications of the basic industrial types of lithium batteries 
«Системні технологіï» 6 (131) 2020 «System technologies»

\begin{tabular}{|c|c|c|c|c|c|c|}
\hline 1 & 2 & 3 & 4 & 5 & 6 & 7 \\
\hline $\begin{array}{c}\text { Specific } \\
\text { output in } \\
\text { terms of } \\
\text { the rated } \\
\text { discharge } \\
\text { current } \\
, \frac{W \cdot h}{k g}\end{array}$ & 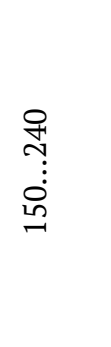 & $\begin{array}{c}\stackrel{\overbrace{}}{0} \\
\vdots \\
\stackrel{N}{0}\end{array}$ & 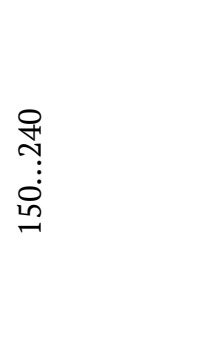 & $\begin{array}{c}0 \\
\stackrel{n}{n} \\
\vdots \\
\vdots \\
8 \\
\end{array}$ & 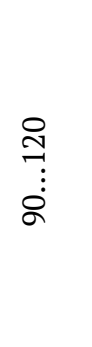 & $\begin{array}{c}0 \\
\vdots \\
\vdots \\
\vdots\end{array}$ \\
\hline $\begin{array}{l}\text { Resource, } \\
\text { cycles }\end{array}$ & $\begin{array}{l}8 \\
\stackrel{0}{0} \\
\vdots \\
\vdots \\
\stackrel{0}{\circ}\end{array}$ & $\stackrel{8}{\circ}$ & 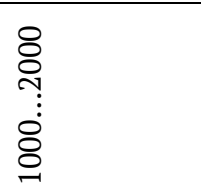 & 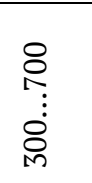 & 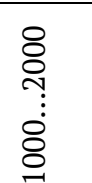 & 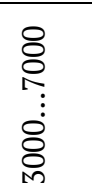 \\
\hline
\end{tabular}

Concerning the idea of the most acceptable electrochemical buttery for supply systems with RES. In the capacity of overall conclusions as for the electrochemical batteries (ECB) considered by the Chapter, it is worth noticing that they are the most popular and the advanced ones among the available storage cells. As for their use by power industry, the major conditions are set forth: high power intensity; rather long operation life (i.e. the number of cycles); no "memory effect"; rapid charge potential; ability to operate in mode of current overload; safe use; and acceptable price.

The analysis helps conclude that no one of the available ECB type meets the requirements. The matter is that LASC are out of rapid charge/discharge modes. Moreover, they have low power intensity; they are not environmentally friendly; and they need specific premises to operate. $\mathrm{NiCd}$ and $\mathrm{NiMH}$ batteries have memory effect and too large self-discharge. Even $\mathrm{LiCoO}_{2}$ and $\mathrm{LiMnO}_{4}$ batteries, characterized by numerous advantages, are too expensive and explosible if operation rules are not adhered to.

Recently developed $\mathrm{LiFePO}_{4}$ storage cells, having all the positive qualities of lithium batteries in addition to allegedly longer operation life, are too expensive. However, their future cheapening may be expected owing to the increased production output. Despite the fact that lithium-titanium batteries are more attractive from the viewpoint of a life cycle (up to 7000 cycles), lithium-iron-phosphatic ones have their own pluses in terms of other indices. Comparative Table II demonstrates quantitative values of the basic characteristics of each electrochemical storage cell. 
Characteristics of the most popular ECB types

\begin{tabular}{|c|c|c|c|c|c|c|}
\hline Battery type & Lead-acid & NiCad & $\mathrm{NiMH}$ & $\mathrm{LiCoO}_{2}$ & $\mathrm{LiMn}_{2} \mathrm{O}_{4}$ & $\mathrm{LiFePO}_{4}$ \\
\hline Nominal voltage, V & 2 & 1.2 & 1.2 & 3.7 & 3.7 & 3.3 \\
\hline Relative cost & 1 & 2 & 2,4 & 4 & 6 & $>10$ \\
\hline Safety & high & high & High & low & average & high \\
\hline $\begin{array}{c}\text { Environmental } \\
\text { friendliness }\end{array}$ & low & low & High & high & high & high \\
\hline Memory effect & - & + & + & - & - & - \\
\hline Energy performance,\% & 60 & 75 & 70 & 90 & 90 & 95 \\
\hline Operation life (cycles) & 400 & 500 & 500 & $>500$ & $>500$ & $>2000$ \\
\hline Charging period, hours & 12 & 1.5 & 4 & $2-4$ & $2-4$ & $<2$ \\
\hline Self-discharge, \%/month & 20 & 30 & 35 & 10 & 10 & 8 \\
\hline
\end{tabular}

Consequently, the analysis helps conclude that $\mathrm{LiFePO}_{4}$ batteries are the most preferable for power lines. That especially concerns railway mains with RES use since the batteries have the best power characteristics. However, their application as accumulators of electric energy, generated by RES, should involve constant control of a charge level of each battery element and their voltage levelling while balancing a state of charge. Consequently, such batteries need rather complicated control system.

Conclusions. Lead-acid SCs, having significant self-discharge, low efficiency, and short useful life prevent from applying so-called floating or regenerating charge-discharge modes, are not applicable for the mains. Especially, it concerns railway power supply systems.

Despite the fact that alkaline SCs can be almost discharged for a long time, withstand high charge/discharge current, and remain serviceable even if undurable short circuits or deep discharge degrees take place, they have considerable selfdischarge (up to $60 \%$ ). In addition, some of them (i.e. NiCad and NiMH storage cells) have memory effect as well. Moreover, DC energizes them for 6-7 hours making their use problematic in supply systems with RES.

High specific power characteristics of lithium storage cells, longer useful life to compare with other electrochemical devices, insignificant self-discharge, lack of memory effect, and available positive practices concerning rapid charge/discharge make them the most appropriate facilities to be used as electric power accumulation in the mains with RES.

$\mathrm{LiFePO}_{4}$ storage cell is the most advantageous among lithium batteries. However, its operation should involve constant control of a charge level of each element 


\section{«Системні технології» 6 (131) 2020 «System technologies»}

and balance of voltage value on them. Thus, complicated system to control them is required.

Anyway, use of the mentioned $\mathrm{LiFePO}_{4}$ storage cell within the supply system of railways (with RESs or without them) is complicated heavily through voltage falls of them when traction loads are connected since they shorten useful life of the accumulator.

\section{REFERENCES}

1. Kochetkova A.E. Application of energy storage as effective direction of energysaving technologies / A.E. Kochetkova // Collection of scientific articles of the AllRussian scientific-practical conference «Current problems of professional and technical education»,10-11 of Novemer, Kursk, Publisher: Kursk State University, pp.221-223.

2. Ulanov N.M. Prospective directions of energy and resource saving at the enterprises of railway transport of Ukraine / N. M. Ulanov, M. N. Ulanov // Railway transport of Ukraine. - 2017. - \# 3. - pp. 9-13. - Access mode: http://nbuv.gov.ua/UJRN/ZTU_2017_3_4.

3. Nezevak V.L., Cheremisin V.T. Application prospects for electric energy storage devices in traction dc power supply system / V.L. Nezevak , V.T. Cheremisin //BULLETIN OF RESEARCH RESULTS.Publisher: Emperor Alexander I St. Petersburg State Transport University (St. Petersburg). - 2015. Number 1 (14) . - pp. 76-83.

4. R. Klein, N. A. Chaturvedi, J. Christensen, J. Ahmed, R. Findeisen and A. Kojic, "State estimation of a reduced electrochemical model of a lithium-ion battery," Proceedings of the 2010 American Control Conference, Baltimore, MD, 2010, pp. 6618-6623, doi: 10.1109/ACC.2010.5531378.

5. Gong, L., Dong, Y., Zhang, L., Lin, M., Cao, S. The modeling and simulation of load-acid buttery on principal component regression (2012) Applied Mechanics and Materials, 220-223, pp. 2809-2813. DOI: 10.4028/www.scientific.net/AMM.220223.2809.

6. Bullich-Massagué, E., Cifuentes-García, F.-J., Glenny-Crende, I., Cheah-Mañé, M., Aragüés-Peñalba, M., Díaz-González, F., Gomis-Bellmunt, O. A review of energy storage technologies for large scale photovoltaic power plants (2020) Applied Energy, 274, DOI: 10.1016/j.apenergy.2020.115213

7. Nefiodov, V.G., Polishchiuk, Yu.V. Electrochemical power industry. Lead batteries: mechanism, manufacturing, calculations: manual. / V.G. Nefiodov, Yu.V. Polishchiuk - Dnipropetrovsk: SHEI “USCTU”, 2013. - 298 pp. 


\section{«Системні технологіï» 6 (131) 2020 «System technologies»}

8. Budko, V. I. Analyzing operational features and specifity of charging modes of nickel- metal-hybrid and lithium storage batteries / V. I. Budko // Renewable power. - 2017. - \# 2. - Pp. 17-25.

9. Handbook of a chemist. Chemical balance and kinetics, properties of solutions, electrode processes / under the editorship of B. P. Nickolskyi. M.-L.: Chemistry, 1965. Volume 3. 1005 pp.

10. GOST 26500-85. Alkaline nickel-iron traction batteries. General specifications. -M., 1985, 28 pp.

11. Kauss, Ya.Ya. Selecting modes to charge nickel-iron diesel locomotive batteries: thesis for the degree of Candidate of Engineering Sciences: 05.05.01 - Leningrad, 1984. - $138 \mathrm{pp}$.

12. IEC 61436:1998 Secondary cells and batteries containing alkaline or other nonacid electrolytes - Sealed nickel-metal hydride rechargeable single cells/ 1998, 25 p.

13. Types of Lithium-ion. [E-resource:

http://batteryuniversity.com/learn/article/types_of_lithium_ion

14. Wenge, C., Pietracho, R., Balischewski, S., Arendarski, B., Lombardi, P., Komarnicki, P., Kasprzyk, L. Multi usage applications of li-ion battery storage in a large photovoltaic plant: A practical experience (2020) Energies, 13 (18), DOI: 10.3390/en 13184590

15. Ranaweera, I.; Midtgard, O.M. Optimization of operational cost for a gridsupporting PV system withbattery storage. Renew. Energy 2016, 88, 262-272.

Received 19.02.2019. Accepted 03.03.2019.

Що до доцільності застосування електрохімічних накопичувачів в системах живлення нетягових споживачів залізниць від альтернативних джерел енергії

Використання та впровадження відновлюваних джерел енергії у таку важливу галузь народного господарства України як залізничний транспорт стає неможливим без наявності пристроїв, які дають можливості накопичувати вироблену електроенергію у великій кількості. Використання акмуляторних пристроїв дозволяє розв'язати питання, які пов'язані з двонаправленими перетоками електроенергії, неприпустимими коливаннями потужності в електричних мережах ( а особливо гостро це питання стосується електрожвилення нетягових споживачів від ВДЕ), що в кінці може призвести до погіршення електромагнітної сумісності у мережі, та інших негативних наслідків. Масштабне впровадження ВДЕ на залізничному транспорті також неможливе без вирішення зазначеного питання. Таким чином в статті розглянуті питання, що до можливостів використання різних електрохімічних засобівв акумулювання електроенергї таких як: свинцево-кислотних акумуляторів; лужних акумуляторів; літієвих акумуляторів. Проведено порівняльний аналіз характеристики найбільш поширених типів електрохімічних акумуляторних батарей. Надані практичні рекомендації, щодо практичного використан- 


\section{«Системні технології» 6 (131) 2020 «System technologies»}

ня останніх в системах живлення нетягових споживачів від ВДЕ в заліничних електромережах.

\section{О целесообразности применения электрохимических накопителей в системах} электропитания нетяговых потребителей железных дорог от возобновляемых

\section{источников энергии}

Рассматриваются различные типы электрохимических накопителей энергии, таких как: свинцово-кислотные аккумуляторы; щелочные аккумуляторы; литиевые аккумуляторы, и вопросы связанные с возможностью их использования в системах питания нетяговых потребителей железнодорожного транспорта от возобновляемых источников энергии. Даны практические рекомендации поо наиболее приемлемым типам, которые есть в наличии на украинском рынке средств аккумулирования электроэнергии. На основании выполненного анализа сравнения технических характеристик различных типов электрохимических накопителей, сделан вывод, что в системах электроснабжения нетяговых потребителей, особенно в сетях питания железных дорог с использованием ВИЭ, предпочтение следует отдавать $\mathrm{LiFePO}_{4}$ аккумуляторам, которые имеют лучшие энергетические характеристики.

Кузнецов Виталий Вадимович - Доцент кафедры Электротехники и электропривода, Национальная металургическая академия Украины, Днепр, Украина, ORCID: http://orcid.org/0000-0002-8169-4598.

Качан Юрий Григорьевич - Профессор кафедры Электроснабжение промышленных предприятий, Национальный университет «Запорожская политехника» Запорожье, Украина, ORCID: http://orcid.org/0000-0001-99843646.

Кузнецов Віталій Вадимович - Доцент кафедри Електротехніки та електропривода, Національна металургійна академія України, Дніпро, Україна ORCID: http://orcid.org/0000-0002-8169-4598.

Качан Юрій Григорович - Професор кафедри Електропостачання промислових підприємств, Національний університет «Запорізька політехніка» Запоріжжя, Україна ORCID: http://orcid.org/0000-0001-9984-3646.

Kuznetsov Vitaliy - Department of the electrical engineering and electromechanic, National metallurgical academy of Ukraine, Dnipro, Ukraine, ORCID: http://orcid.org/0000-0002-8169-4598.

Kachan Yuriy - Department of the Power supply of industrial enterprises, Zaporizhzhia Polytechnic National University, Zaporizhzhia, Ukraine, ORCID: http://orcid.org/0000-0001-9984-3646. 